\title{
AN EXAMINATION OF OVULATION RATIO IN NATURALLY OVULATING AND INDUCED INBRED AND OUTBRED MICE
}

\author{
E. P. KELLY \\ Department of Veterinary Hygiene and Husbandry, University College Dublin, \\ Ballycoolin Road, Dublin 11, Ireland \\ (Received 14th Fanuary 1971)
}

\begin{abstract}
Summary. The total number of eggs shed between the left and right ovaries of 728 induced inbred mice of the $Q$ strain differed significantly $(P<0.01)$ from binomial expectation. Total ovulations from three eggs to eleven eggs also differed significantly $(P<0.01)$ from binomial expectations in the distributions of differences between sides. However, the latter deviation was randomly distributed between sides. The effects of line, dose and weight were not significant.
\end{abstract}

Falconer, Edwards, Fowler \& Roberts (1961) reported on the differences in the numbers of eggs shed by the two ovaries of mice during natural oestrus and after superovulation. Their findings were in borderline agreement with the expected 50:50 ratio between the left and right ovary. McLaren (1963), in a study of ovulation rate and embryonic survival, showed that the right side tended to be reproductively superior to the left in mice.

In the course of a broader experiment, sufficient data has emerged to examine the same effects in induced inbred and outbred mice of the $Q$ strain. A lesser set of data in outbred controls is included for comparison. Outbred mice were the random culls of a production experiment from the laboratory of Dr V. Timon, Agricultural Institute, Dunsinea, Co. Dublin. Inbred mice consisted of the progeny of sub-lines within seven brother-sister mated lines; the coefficient of inbreeding (F) was between $73 \%$ and $74 \%$.

Follicular growth was induced using HCG (Organon Laboratories Ltd, London) at dosages of $0.25,0.5,1.0,2.0$ and 4.0 i.u. Ovulation was induced using a constant dosage of 3 i.u. LH (Lutormone, Burroughs Welcome Ltd, London). The induction technique employed was the same as in the procedure of Fowler \& Edwards (1957). The intraperitoneal injection site was on the mid-line, between the posterior pair of mammae. Only those mice which did ovulate were scored. The method was successful in causing ovulation in $96 \%$ of all treated mice. Natural ovulation was determined upon necropsy, following observation of a vaginal plug subsequent to paired matings. The distribution of total counts for the induced inbred mice showed a significant deviation $(P<0.01$, Table 1$)$ towards the right ovary.

The data on induced inbreds were then arranged in the manner shown in 
Table 2 and total ovulations between one and fifteen eggs examined. For convenience, only four egg totals are shown. The method of analysis of Falconer et al. (1961) was followed. Expected values for the binomial distribution were generated by computer; the program also calculated individual and pooled chi-square values for each egg total.

The distribution of differences between right and left sides of induced inbred mice between three and eleven eggs inclusively, differed significantly $(P<0.01)$

Table 1

COMPARISON OF LEFT AND RIGHT OVULATIONS OF INDUCED INBRED AND OUTBRED MICE

\begin{tabular}{l|c|c|c|c}
\hline \multirow{2}{*}{ Class } & \multirow{2}{*}{ No. of mice } & \multicolumn{3}{|c}{ No. of eggs } \\
\cline { 2 - 5 } & & Left & Total & $\%$ Left \\
\hline Induced inbreds & 728 & 3094 & 6459 & $47.9 * * *$ \\
Induced outbreds & 231 & 1121 & 2213 & $50 \cdot 65$ \\
Pooled & 959 & 4215 & 8672 & 48.60 \\
\hline \multicolumn{3}{c}{$* * * P<0.001}$.
\end{tabular}

TABLE 2

OBSERVED DIFFERENCES BETWEEN SIDES COMPARED TO THE BINOMIAL EXPEGTATION IN INDUCED INBRED MICE

\begin{tabular}{|c|c|c|c|c|c|c|c|c|c|}
\hline \multirow{2}{*}{$\begin{array}{c}\text { Total no. } \\
\text { of eggs }\end{array}$} & \multirow{2}{*}{ No. of mice } & & \multicolumn{6}{|c|}{ Difference between sides } & \multirow{2}{*}{$\begin{array}{l}\text { Chi- } \\
\text { square }\end{array}$} \\
\hline & & & 0 & 2 & 4 & 6 & 8 & 10 & \\
\hline 4 & 34 & $\begin{array}{l}\text { Exp. } \\
\text { Obs. }\end{array}$ & $\begin{array}{c}12 \cdot 75 \\
9\end{array}$ & $\begin{array}{l}17 \cdot 0 \\
11\end{array}$ & $1^{4 \cdot 25}$ & - & - & - & $27 \cdot 06^{* * *}$ \\
\hline 6 & 49 & $\begin{array}{l}\text { Exp } \\
\text { Obs. }\end{array}$ & $\begin{array}{l}15 \cdot 3 \\
14\end{array}$ & $\begin{array}{l}22 \cdot 8 \\
20\end{array}$ & $\begin{array}{l}9 \cdot 18 \\
8\end{array}$ & $\frac{1 \cdot 52}{7}$ & - & 二 & $27 \cdot 19 * * *$ \\
\hline 8 & 65 & $\begin{array}{l}\text { Exp. } \\
\text { Obs. }\end{array}$ & $\begin{array}{l}17 \cdot 8 \\
16\end{array}$ & $\begin{array}{l}28 \cdot 4 \\
21\end{array}$ & $\begin{array}{l}14 \cdot 2 \\
16\end{array}$ & $\begin{array}{l}4 \cdot 0 \\
4\end{array}$ & $\begin{array}{l}0.5 \\
8\end{array}$ & - & $114 \cdot 19 * * *$ \\
\hline 10 & 80 & $\begin{array}{l}\text { Exp. } \\
\text { Obs. }\end{array}$ & $\begin{array}{l}19 \cdot 7 \\
15\end{array}$ & $\begin{array}{l}32 \cdot 8 \\
33\end{array}$ & $\begin{array}{l}18 \cdot 7 \\
23\end{array}$ & $\begin{array}{l}7 \\
2\end{array}$ & $3^{1 \cdot 6}$ & $\begin{array}{l}0 \cdot 15 \\
4\end{array}$ & $108 \cdot 87 * * *$ \\
\hline
\end{tabular}

Exp. $=$ expected; Obs. $=$ observed.

*** $P<0.001$.

from the binomial expectation. A similar analysis of the induced outbreds was in complete agreement with expectation, except for one mouse ovulating a total of eleven eggs, all of which were from the right ovary. This, however, was the exception when egg totals from three to fifteen were examined.

The induced inbred data were further examined to see if there was a trend towards one ovary consistently contributing a greater ratio. In contradiction to what would appear from Table 1, the distribution of extreme ratios (i.e. 9:1, $1: 12$ ) was random between left and right ovaries. Thus, although total ovulation of the 728 inbred mice showed a significantly greater number of eggs being 
ovulated from the right ovary, the distribution between sides within egg total classes showed a random distribution between sides. Both these effects were confined to induced inbred mice. This random distribution of extreme ratios between sides may eliminate the site of injection as a probable source of experimental bias. Histological examination of ovaries was not included in this study. No significant deviation from expectation was found in the similar analysis of naturally ovulating inbreds and outbreds nor of similarly induced outbreds.

A least squares analysis of variance was performed on the induced inbred data to examine the effects of lines, doses, weight and interaction effects. In this instance, ovulation ratio was scored as the number of eggs ovulated from the right ovary of each mouse divided by the total number of eggs ovulated by that mouse. All main effects were non-significant.

I would like to thank Dr D. Kelleher, Faculty of Agriculture, University College Dublin, for statistical and programming assistance in the course of this work.

\section{REFERENCES}

Falconer, D. S., Edwards, R. G., Fowler, R. E. \& Roberts, R. C. (1961) Analysis of differences in the numbers of eggs shed by the two ovaries of mice during natural oestrus or after superovulation. 7. Reprod. Fert. 2, 418.

FowLER, R. E. \& EDWARDs, R. G. (1957) Induction of superovulation and pregnancy in mature mice by gonadotrophins. F. Endocr. 15, 374 .

MaLaren, A. (1963) The distribution of eggs and embryos between sides in the mouse. F. Endocr. 27, 157. 